\title{
ALGORITHM OF REVITALIZATION PROGRAMME DESIGN FOR HOUSING ESTATES
}

\author{
Anna OSTAŃSKA ${ }^{1}$ \\ Lublin University of Technology, Civil Engineering and Architectural Department, \\ Lublin, Poland
}

\begin{abstract}
Demographic problems, obsolescence of existing buildings, unstable economy, as well as misunderstanding of the mechanism that turn city quarters into areas in need for intervention result in the implementation of improvement measures that prove inadequate. The paper puts forward an algorithm of revitalization program for housing developments and presents its implementation. It also showed the effects of periodically run (10 years) three-way diagnostic tests in correlation with the concept of settlement management.
\end{abstract}

Keywords: revitalization, corrective actions, residential settlement

\section{INTRODUCTION}

Housing estates erected decades ago, technically sound but functionally dated, require the appointment of a deliberate course of actions in order to meet contemporary expectations of residents. Environmental psychology asks questions often ignored by decision makers of development of housing areas: What can and should be done to ensure in people a sense of life quality in a standard building? How to deal with aging people, or people with disabilities, in densly populated metropolitan housing estates? How to prevent vandalism, social disintegration and crime? [1,2].

\footnotetext{
${ }^{1}$ Corresponding author: Lublin University of Technology, Civil Engineering and Architectural Department, Institute of Architecture, Urban Planning and Space Planning, Nadbystrzycka st 40, 20-618 Lublin, Poland, e-mail: a.ostanska@ pollub.pl, tel.+48 603656563
} 
Poland is struggling with problems of low birth rate and aging of the society, which means changes to the structure of households and expectations towards living environment. The buildings, the space between them, the infrastructure and systems are becoming obsolete. The sizes of apartments, their functionality, finishings and technical installations no longer meet the needs of residents, especially those with disabilities. This causes migration of the more prosperous to other, more valued, settlements in new estates, to the suburbs or countryside. To avoid decline of the neighbourhoods and to make them more attractive, one could think, among others, of introducing modern technology to the "old" housing environment, e.g. environmentally friendly systems reduce consumption of natural resources, and techniques to restrain socially unaccteptable behaviour and crime (e.g. monitoring of settlements). With the economies of scale (the demand from multifamily housing estates), a well planned investment in this area is likely to positively affect household budgets, and even build enough demand to boost the market of modern technologies, thus creating jobs ${ }^{2}[3]$.

Urban revitalization is to stop and reverse unwelcome trends in the neighbourhoods. As it is better to prevent than to cure, the author puts forward that the understanding of revitalization should be stretched beyond problems of areas already dilapidated [1]. Thus, the current revitalization of housing estates should be understood as a comprehensive set of measures taken to maintain or achieve a good status of the area, to improve the living conditions of the local community at home and in the neighbourhood. The measures involve humanizing the estates by means of activities aimed at social and economic recovery, to stop the process of depopulation ${ }^{3}$ and decapitalisation of the stock.

\section{PROPOSED ALGORITHM OF REVITALIZATION PROGRAM FOR RESIDENTIAL ESTATES}

\subsection{Background}

In the last decade, the author attempted to determine the course of actions in the revitalization process [1]. On this basis, a tool in the form of a revitalization algorithm was proposed, and its application was shown in the example of

\footnotetext{
2 "It is estimated that at the end of 2013 outside the Polish borders, there were about 2.196 thousand inhabitants of our country, i. e. about 66 thousand $(3.1 \%)$ more than in 2012 (about 2.130 thousand)" [3].

${ }^{3}$ What Niezabitowska said recently at a conference in Katowice on $22^{\text {nd }}$ September 2014.
} 
a housing estate in Lublin. One of the aims of the analysis was to find small changes to the fabric of the prefabricated buildings that open, for the architect, a possibility of upgrading them. Sets of solutions put forward at that time were purely technical and based on studies at the basic level. However, limitations of a purely technical approach were noticed, and the direct result of the study [1] was a proposal of scientific and technical procedure for activities to develop a revitalization program dedicated to prefab housing estates. The problems observed in numerous buildings erected in a number of different prefabrication systems, and in several housing estates, proved to be similar, thus the author claimes that this systemic approach is of universal character.

Revitalization of prefabricated housing estates is a difficult task due to engineeering complexity of physical ingerention to the structure, financial limitations, and lack of interest of the decision makers. The problem of these estates is, surprisingly, that they are in no direct structural danger and their physical dilapidation not an imminent problem (apart from the threat from facade insulation falling off due to bad workmanship while anchoring insulation to sandwich panels): deterioration process is creeping, and problems of the neighbourhoods cumulate too slowly to raise immediate intrest of the public.

Recently, nothing happens at the state level or local level (municipality, district, housing estate) in terms of modernisation policies for this type of housing stock. There is no wider perspective and comprehensive implementation of revitalization programs for housing developments: the unseen hand of the market is to solve it.

Observing the activity of housing estate managers and the public support policies (thermomodernisation funds), one has mainly taken actions to improve the aesthetics of the estate and to reduce energy consumption by applying insulation and new claddings. Current thermographic tests confirm that despite many stages of building insulation, there are still problems with excessive heat losses. Energy use in buildings and housing estate is also not optimal only because of the monopolized way of heat supply to the estate.

\subsection{The algorithm to design housing estate revitalization programme}

Formulation of proposals for improvement measures needs to be based on a thorough investigation of current condition of the housing stock. To provide complete and reliable input, a procedure adapted to current conditions was proposed (Figure 1, [1]). On its basis one assessed the actions, derived from the guidelines, leading to proposals for revitalization programs of housing estates regardless of the type of buildings and construction methods.

The proposed revitalization algorithm involves a three aspect analysis and consists of seven stages. In the first stage of the revitalization algorithm 
provides a general examination and description of settlement. In particular, this is a collection of data relating: location and layout of the analyzed area, the age of objects, the type of residential development and problems associated with it, the accompanying building and infrastructure of settlement, which will allow for predicting social problems and raise questions to residents.

In the second stage, one performs diagnostic tests, drawn up on the basis of the fundamental aspects, carried out both for individual residential buildings and associated facilities (commercial buildings, garages, garbage cans, playgrounds, squares, pavements, roadways), with infrastructure (networks and connections).

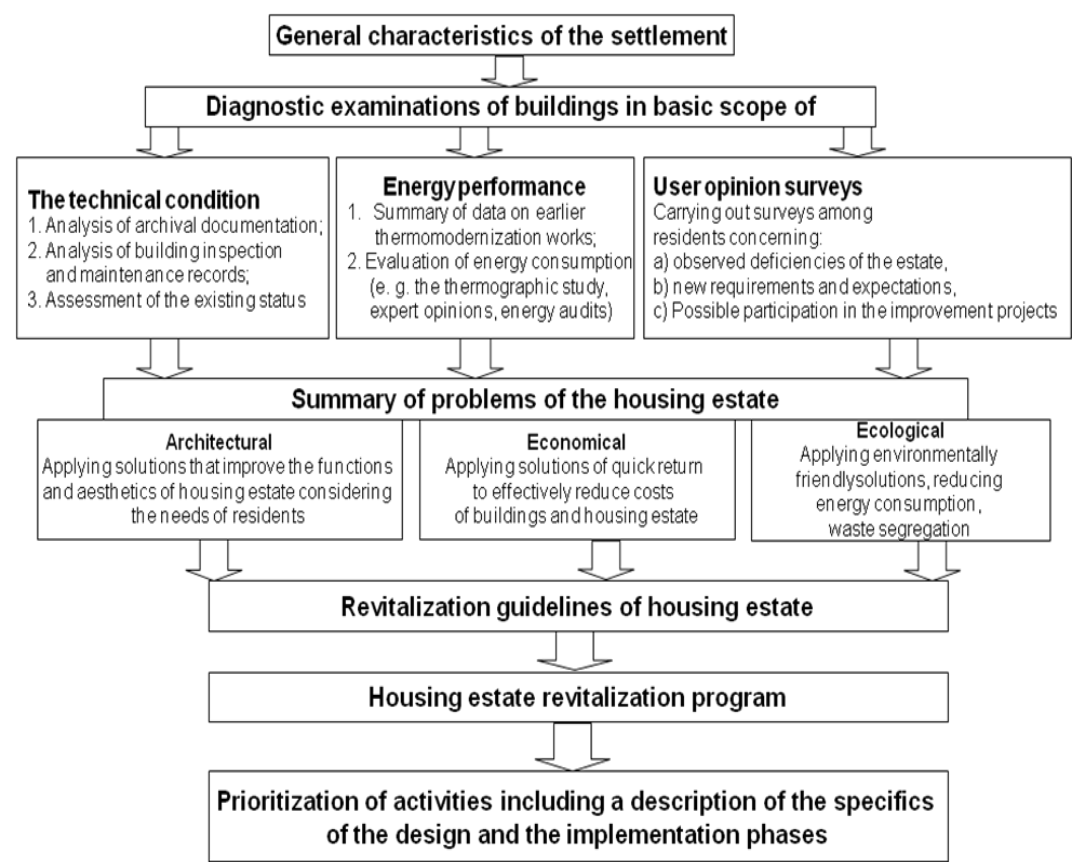

Fig 1. Algorithm for proposals for the revitalization of housing estates

Diagnosis, in the technical aspect, is the evaluation of physical condition of the housing stock ans assessment of its utility value of individual objects. Analysis of archival documentation, including compulsory annual and five-year inspections and facilities books [4] conducted by the author in several locations revealed that inspections are often superficial, and the maintenance records incomplete. Still, they are meant to provide insight into the technical condition of the building and are to be checked in the process of preparing the diagnosis. Moreover, evaluation of the value in use [5], determining the degree of wear and tear of buildings, e. g. by weighted repair based on [6] provide useful input. The proposed scope of technical analysis is broader than this of the method of 
weighted repair assumptions [6] by the planning of renovation actions and putting forward sets of specific solutions.

Diagnostics in terms of energy performance is an evaluation of energy consumption and includes summary data concerning earlier measures to reduce energy consumption, and to assess actual energy consumption (thermographic surveys, energy audit of buildings and settlements).

Diagnosis in the social aspect conducted in direct interview is to supply information on the social structure of the estate, residents' opinions on the estate's deficiencies, buildings, and dwellings, and to assess the inhabitant's willingness to participate in the activities of revitalization. Such surveys provide also an insight into the flat user's own modifications. Normally, the facility manager has a very limited knowledge on what was done in private premises.

In stage III, the problems defined in the previous steps are juxtaposed and divided for these concerning the estate at large, particular buildings, infrastructure and facilities, and their particular components.

Stage IV is devoted to defining specific solutions to the above problems with consideration to additional, estate-specific aspects (structural, architectural, environmental etc.). The selected improvement measures should match financial capacities and offer possibility of reducing energy consumption and operating costs of housing and the estate's infrastructure.

Stage V establishes guidelines for the estate revitalization program. The author proposes that four types of actions should be considered, and their consequences examined: maintain as it is, repair, replace, for each building, piece of infrastructure or component in question. This requires multidisciplinary knowledge, thus a team of experts should be appointed for these tasks.

In Stage VI, the revitalization program for the estate is finally decided.

Stage VII - the programme is represented as a set of projects (or actions) and their optimal sequence is established.

The presented algorithm seems to be a response to the needs of the revitalization process of housing estates. Stages I - III are possible to be conducted by a representative of one engineering discipline. However, singlediscipline solutions in stage IV would be insufficient, thus cooperation of representatives of other disciplines is necessary, especially for comprehensive project proposals and selection of technical measures. Stages V - VII require a co-operation of a multidisciplinary team of specialists, not only engineers, but also representatives of all parties involved (estate managers, users).

To test the assumptions and verify the structure of the algorithm, it was applied to the input analysis and construction of a revitalization programme proposal for a selected residential estate. 


\section{APPLICTION OF THE ALGORITHM: ANALYSIS OF A HOUSING ESTATE}

A basic assessment on the estate's condition was conducted in one of Lublin housing estates of Czechów Housing Cooperative, erected in nineteenseventies. The analysis covered three aspects: technical condition of assets, energy performance, and user opinion [1].

The estate has been subject to a series of improvement projects with regard to buildings and estate's infrastructure. Interestingly, the housing cooperative has not applied for EU funds yet, despite such funds are available, for example on improving security. These funding programs expire with the end of 2020.

The analysis revealed that the buildings of the analyzed housing complex do not have a satisfactory technical equipment (obsolete MEP systems), and previous actions aimed at improving energy performance were incomplete (limited to insulating the building's envelope, refurbishment of local heat distribution network and replacement of heat exchangers that serve groups of buildings).

The user opinion survey (direct interviews) provided a very useful insight: the inhabitants were often not aware of what improvements had been already done. They also asked when new measures would be taken and how much would they cost, and expressed interest in them. Many would like to pay extra for selected improvements, on top of the cooperative's repair and modernization fund.

The above mentioned analyses enabled the author to prepare a list of problems worth solving by taking revitalisation measures [1]. The estate was checked again: after 5 and 10 years from the initial survey. The author concluded that the combination of problems, based on the results of three-aspect diagnostic tests may constitute the current basis for constructing initial guidelines for the revitalization program, not only in terms of further functioning and operation of particular buildings, but for the whole estates.

The lack of strategic thinking is a recurrent problem: the estate managers focus on current maintenance problems (and solve them efficiently) but do not try to exploit possibility of affecting the municipal housing policies and entering into strategic improvement programmes with access to funding opportunities. Such opportunities may expire soon. Moreover, the estate management fails to:

- understand the effects of thermomodernization works completed so far,

- identify the needs and opportunities for technical modernization, improving the quality of life and environment,

- plan comprehensive long-term actions (in perspective above 5 years).

Despite the lapse of time (2004-2014), practically all issues defined in [1] are still present in the analyzed estate. Many important improvements have been done: playgrounds for children have been modernized, the number of parking 
spaces was increased. However, the problems of fire safety (e. g. access to buildings for emergency services) have not been solved, recreation places for the elderly have not been provided, architectural bareers have not been removed (ingress/ egress access for the disabled and elderly).

\section{CONCLUSIONS}

The systematic approach for analyzing the housing environment, as proposed in the form of the algorithm to design housing estate revitalization programmes, is useful first to get the overall picture of the estate's needs.

The case provided as example proved that the management's actions (lacking such overall picture) were not sufficient to bring the residential buildings to the current requirements. Periodic checks confirmed that security improvements were neglected, as were the problems of some social groups and the potential of financial participation in improvements declared by the inhabitants.

As confirmed by the opinion survey, the residents' priority is to improve the living conditions. This applies to people of all ages, nature and degree of the affliction. The user's approval of any improvement measures affects the user's willingness to participate in costs related to the planned revitalization, and is often a condition sine qua non for the success of projects. Opinion of the residents may also direct the sequence of tasks. Therefore, the estate management should not be reluctant to ask direct questions. The questionnaire similar to the one developed for the research would be useful as a tool in the process of defining the housing estates regeneration programs.

Summing up, the guidelines for the revitalization program may be established on the basis of the diagnosis carried out in the three-aspect basic range. As the problems that need solving are not only of technical character, is necessary to involve representatives of other disciplines whose opinions and studies in their respective aspects, allow the project managers to find exhaustive solutions. It is possible to apply the proposed algorithm to revitalization of other type, but it requires the involvement of administrators.

\section{ADDITIONAL INFORMATION}

This work was financially supported by Ministry of Science and Higher Education in Poland within the statutory research number S/19/2/2015. 


\section{REFERENCES}

1. Ostańska A.: Podstawy metodologii tworzenia programów rewitalizacji duzych osiedli mieszkaniowych wzniesionych $w$ technologii uprzemystowionej na przykladzie osiedla im. St. Moniuszki w Lublinie, Politechnika Lubelska, Monografie Wydziału Inżynierii Budowlanej i Sanitarnej Vol.1, Wydawnictwa Uczelniane Lublin 2009, 1-173.

2. Bańka A.: Spoleczna psychologia środowiskowa - seria wykłady z psychologii. Wydawnictwo Naukowe SCHOLAR 2002, s. 266.

3. Kostrzewa Z., Szałtys D., Marciniak G.: Informacja o rozmiarach i kierunkach czasowej emigracji z Polski w latach 2004 - 2013, Główny Urząd Statystyczny, Departament Badań Demograficznych i Rynku Pracy. Warszawa, październik 2014, s. 2.

4. Ustawa prawo budowlane z dnia 7 lipca 1994r. Dz.U. z 2003r. nr 207, poz. 2016 z późniejszymi zmianami (art. 61. ustęp: 1 i 2).

5. Niezabitowska E., Kucharczyk-Brus B., Masły D.: Wartość użytkowa budynku, Verlag Daschöfer 2003, s. 10, 12.

6. Knyziak P., Witkowski M.: Ocena stanu technicznego prefabrykowanych budynków mieszkalnych $w$ Warszawie, „Inżynieria i Budownictwo” nr 12/2007, s. 639-641.

\section{PROPOZYCJA ALGORYTMU PROGRAMU REWITALIZACJI DLA OSIEDLI MIESZKANIOWYCH}

\section{Streszczenie}

Problemy demograficzne, zużycie moralne eksploatowanych budynków i niestabilna gospodarka, a także niezrozumienie mechanizmu powstawania obszarów rewitalizacji skutkują realizacją działań, które dziś są niewystarczające. W artykule przedstawiono propozycję i zastosowanie algorytmu programu rewitalizacji dla osiedli mieszkaniowych. Pokazano też efekty prowadzonych cyklicznie (od 10 lat) trójaspektowych badań diagnostycznych w korelacji z koncepcją zarządzania osiedlem.

Słowa kluczowe: rewitalizacja, działania naprawcze, osiedle mieszkaniowe

Editor received the manuscript: 09.12.2014 